\title{
Developed Sauces by Using Vegetables and its Utilization in Recipe
}

\author{
Singh Ritika ${ }^{1}$, Singh Neetu ${ }^{2}$ \\ ${ }^{1}$ Student, Department of Food and Nutrition, School for Home Sciences, Babasaheb Bhimrao Ambedkar University (A Central University), \\ Vidya Vihar, Rae Bareli Road, Lucknow- 226025(U.P.), India \\ ${ }^{2}$ Assistant Professor, Department of Food and Nutrition, School for Home Sciences, Babasaheb Bhimrao Ambedkar University (A Central \\ University), Vidya Vihar, Rae Bareli Road, Lucknow- 226025(U.P.), India
}

\begin{abstract}
The basic methods of vegetables preserving methods include dehydration, salting, pickling, fermentation, canning, and freezing. Pickling and fermentation are old methods of preserving various horticultural crops, and unique methods of pickling and fermentation have long been developed. There are various types of pickling and fermentation products in Asia.The influence of storage temperature of vegetables and chemical additives ( including ascorbic acid, citric acid and potassium sorbate) on the chemical, physical, microbiological and sensory characteristics of vegetables was evaluated. Vegetable sauces was processed, packed and thermally treated. The colour of vegetable sauces was affected by chemical treatment, temperature and storage period.
\end{abstract}

\section{Introduction}

Sauce is usually thick liquid that is poured over other food in order to add moisture and flavor. A Sauce is a seasoned liquid used as an ingredient and dishes, and as a condiment. As a condiment, it may be applied just before serving, or set at the table for a dinner to apply him or herself. Sauces can be savoury, sweet, sour, or sweet and sour.

Carrot is a root vegetable, usually orange in colour, though purple, black, red, white and yellow in colour The most commonly eaten part of the plant is the taproot, although the greens are sometimes eaten as well. The Carrot is a biennial plant in the umbellifer family Apiaceae, At first, it grows a rosette of leaves while building up the enlarged, fastgrowing cultivars mature within three months ( 90 days) of sowing the seed, while slower- maturing cultivars are harvested four months later ( 120 days) Carrots are widely used in many cuisines, especially in the preparation of salads, and carrot salads are a tradition in many regional cuisines.Carrots can be stored for several months in the refrigerator or over winter in a moist, cool place. For long term storage, unwashed carrots can be placed in a bucket between layers of sand, a 50/50 mix of sand and wood shavings, or in soil. A temperature range of 32 to $40^{\circ} \mathrm{F}$ is best..

Beetroot (sometimes called table beet, garden beet, red or golden beet, or just beet) is a taproot part of the beet plant. It is used for nourishment, but it also has use in food coloring and medicine Beetroot can be eaten raw and shredded into a salad (alone or with other vegetables), boiled, cooked, pickled, or cold as a salad after cooking. Originating in Ukraine, borscht is a beetroot soup popular in many countries of Eastern and Central Europe. Other ingredients in borscht are beef or pork broth, potatoes, carrots, and peppers Beetroot for a hot variant, and sour cream, soured milk, kefir, yogurt, buttermilk, radishes or cucumbers for a cold variant of borscht .Poland has Cwikla a mix of beetroot and horseradish which goes as a salad with cold cuts and sandwiches or a side dish with meat and potatoes. Beetroot is frequently added as an ingredient to salads, soups and pickles and is also used as a natural coloring agent. Even though beets are available throughout the year, they are still considered seasonal vegetables. Besides their use as an actual food item, beets are valuable as a source of sucrose, which makes them a viable replacement for tropical sugar cane. They are still frequently used to make refined sugar.

Radish, that are common part of salad, is a root crop, and it is pungent or sweet in taste with a lot of juice. Radishes can be white, red, purple or black, and in terms of shape, it can be long and cylindrical, or round. They are eaten raw, cooked or pickled. The oil obtained from the seeds of radish is also used in a number of products and beneficial health applications.

The parts of radishes that are commonly consumed are the leaves, flowers, pods and seeds. The scientific name of radish is Raphanus Sativus which belongs to the Brassicaceae family. Radish is also known as Daikon in some parts of the world, primarily in Asian markets.

Garlic (Allium sativum), a herb used widely as a flavoring in cooking, has also been used as a medicine throughout ancient and modern history to prevent and treat a wide range of conditions and diseases.Garlic belongs to the onion genus Allium, and is closely related to the onion, rakkyo, chive, leek, and shallot. It has been used by humans for thousands of years and was used in Ancient Egypt for both culinary purposes and its health and therapeutic benefits.

Garlic has been used all over the world for thousands of years. Records indicate that garlic was in use when the Giza pyramids were built, about five thousand years ago. Richard S. Rivlin wrote in the Journal of Nutrition that the ancient Greek physician Hippocrates (circa. 460-370 BC), known today as "the father of Western medicine", prescribed garlic for a wide range of conditions and illnesses. Hippocrates promoted the use of garlic for treating respiratory problems, parasites, poor digestion and fatigue.

\section{Volume 6 Issue 12, December 2017}




\section{International Journal of Science and Research (IJSR) \\ ISSN (Online): 2319-7064}

Index Copernicus Value (2016): 79.57 | Impact Factor (2015): 6.391

Mint is as tasty as it is healthy. Its essential oil is widely used in manufactured products such as toothpaste, shower gel and medicines for its naturally antibacterial and cooling qualities. In cooking, mint sprigs can be added to cooking water or the chopped leaves incorporated into a dish to make the most of this herb's aromatic, flavoursome and digestive abilities. Mint leaves is originated in Asia and the Mediterranean region, mint has been known for its many benefits throughout history. Greeks used to clean their banqueting tables with the herb and added it to their baths to stimulate their bodies, whilst Romans used it in sauces, as an aid to digestion and as a mouth freshener. Medieval monks drew on the herb for its culinary and medicinal properties.Mint derives its name from the ancient Greek mythical character Minthe. According to Greek myth, Minthe was a river nymph. Hades, the God of the Underworld, fell in love with Minthe and when Persephone, Hades's wife, found out, she turned Minthe into a plant, so that everyone would walk all over her and crush her. Unable to undo the spell, Hades gave Minthe a magnificent aroma so that he could smell her and be near her when people trod on her.

Coriander is one of the from Pylos refers to the species as being cultivated for the manufacture of perfumes, it apparently was used in two forms: as a spice for its seeds and as a herb for the flavour of its leaves. This appears to be confirmed by archaeological evidence from the same period; the large quantities of the species retrieved from an Early Bronze Age layer at Sitagroi in Macedonia could point to cultivation of the species at that time.Coriander was brought to the British colonies in North America in 1670, and was one of the first spices cultivated by early settlers. coriander leaves are commonly present at each home on Indian family. They use coriander for garnishing, making chutneys or in parathas. Its dark green colour makes it more attractive and appealing to eat.

\section{Objective}

- To analyse sensory character of sauces.

- To evaluate self life of develop product.

\section{Methodology}

Study Area- The study was conducted in the research laboratory of the Department of Food Science and Technology, BBAU, Lucknow and in the analysis laboratory of RFRAC ( Regional Food Research and Analysis Centre) situated in Lucknow.

Period of the study- The present study conducted during the period of 2016-2017 session in the whole work comprising period of July 2016-May 2017.

Tool sensory evaluation card is used as a tool for scoring and evaluation

Score card for sensory evaluation of the products

Name:

Product:

Time of evaluation:
Test the sample and check how much you like or dislike each one. Use appropriate scale to show your attitude by checking at the point that best describe your feeling about the sample.

\begin{tabular}{|c|c|}
\hline Hedonic Table and Rating. & Score \\
\hline Like extremely & 9 \\
\hline Like very much & 8 \\
\hline Like moderately & 7 \\
\hline Like slightly & 6 \\
\hline Neither like nor dislike & 5 \\
\hline Dislike slightly & 4 \\
\hline Dislike moderately & 3 \\
\hline Dislike very much & 2 \\
\hline Dislike extremely & 1 \\
\hline
\end{tabular}

\begin{tabular}{|c|c|c|c|c|}
\hline Product & $\begin{array}{c}\text { Flavour and } \\
\text { Taste }\end{array}$ & $\begin{array}{c}\text { Body and } \\
\text { Texture }\end{array}$ & $\begin{array}{c}\text { Colour and } \\
\text { Appearance }\end{array}$ & $\begin{array}{c}\text { Overall } \\
\text { Acceptability }\end{array}$ \\
\hline T1 & & & & \\
\hline T2 & & & & \\
\hline T3 & & & & \\
\hline
\end{tabular}

\section{Comment:}

Name:

Signature:

\section{Results}

\section{Sensory evaluation}

Sensory evaluation of vegetables sauces was done by the 5 member panellist. Four parameters were used to analyse the acceptability of developed product these are as below-

- Body and Texture

- Color and Appearance

- Flavor and Taste

- Overall Acceptability

Table 1: Individual markings for flavour and taste

\begin{tabular}{|c|c|c|c|}
\hline Members & T1 & T2 & T3 \\
\hline 1 & 8 & 9 & 7 \\
\hline 2 & 8 & 9 & 8 \\
\hline 3 & 8 & 9 & 8 \\
\hline 4 & 9 & 8 & 7 \\
\hline 5 & 8 & 9 & 8 \\
\hline Total & 41 & 44 & 38 \\
\hline
\end{tabular}

- Where,T1= Garlic, radish sauce

- $\mathrm{T} 2=$ Beetroot, carrot sauce

- T3=Mint, coriander sauce

Table 2: Individual Markings for body and Texture

\begin{tabular}{|c|c|c|c|}
\hline Members & T1 & T2 & T3 \\
\hline 1 & 9 & 8 & 8 \\
\hline 2 & 7 & 8 & 8 \\
\hline 3 & 9 & 9 & 8 \\
\hline 4 & 9 & 8 & 6 \\
\hline 5 & 8 & 8 & 8 \\
\hline Total & 41 & 41 & 38 \\
\hline
\end{tabular}

The above mentioned table represent score of individual marking by 5 panel list members on the basis of body and texture, the minimum average scored is 38 by $\mathrm{T} 3$ while maximum is $\mathrm{T} 1$ and $\mathrm{T} 2$ with an average of 41 , which shows the highest acceptability of body and texture. 


\section{International Journal of Science and Research (IJSR) \\ ISSN (Online): 2319-7064}

Index Copernicus Value (2016): 79.57 | Impact Factor (2015): 6.391

Table 3: Individual Markings for Colour And Appearance

\begin{tabular}{|c|c|c|c|}
\hline Members & T1 & T2 & T3 \\
\hline 1 & 8 & 9 & 8 \\
\hline $\mathbf{2}$ & 9 & 9 & 9 \\
\hline $\mathbf{3}$ & 9 & 8 & 8 \\
\hline $\mathbf{4}$ & 9 & 8 & 6 \\
\hline $\mathbf{5}$ & 8 & 8 & 9 \\
\hline Total & 43 & 42 & 40 \\
\hline
\end{tabular}

The above mentioned table represent score of individual marking by 5 panel list members on the basis of color and appearance, the minimum average scored is 40 by T3 while maximum is $\mathrm{T} 1$ with an average of 43 , which shows the highest acceptability of color and appearance.

Table 4: Individual Markings for Overall Acceptability

\begin{tabular}{|c|c|c|c|}
\hline Members & T1 & T2 & T3 \\
\hline 1 & 8 & 8 & 8 \\
\hline 2 & 8 & 9 & 8 \\
\hline 3 & 9 & 9 & 8 \\
\hline 4 & 9 & 8 & 7 \\
\hline 5 & 8 & 9 & 8 \\
\hline Total & 42 & 43 & 39 \\
\hline
\end{tabular}

The drawn table represent score of individual markings by panelist members and their average marks of overall acceptability, the minimum average scored is 39 by T3 while maximum is of $\mathrm{T} 2$ with an average of 43 , which shows the highest acceptability of sample T2 in respects of products overall acceptability.

\section{Conclusion}

The sensory evaluation of the vegetable sauces was done by using 9- point hedonic scale by a panel of 5 members. The scoring for each of the samples of sauces by various parameter i.e. flavour, taste, texture, colour, appearance and overall acceptability. There were 3 samples of different percentage of ingredients but by sensory evaluation card the sample T2 with (100 gm Beetroot and 100 gm Carrot) vegetable sauce was most accepted among the three.

\section{References}

[1] Nafiseh Zamindar1,MahsaSadrarham andMonirDoudi, Antifungal activity of coriander (Coriandrumsativum L.) essential oil in tomato sauce, Received: 15 June 2015 / Accepted: 25 April 2016.

[2] NaziaMasood Ahmed Chaudhry and Perween Tariq, Bactericidal activity of black pepper, bay leaf, aniseed and coriander against oral isolates, Pak. J. Pharm. Sci., 2006, Vol.19(3), 214-218.

[3] P. Nisha ,Rekha S. Singhal\&Anirudha B. Pandit , Degradation of colour in beetroot (Beta vulgaris L.):a kinetics study, Revised: 15 April 2012 / Accepted: 8 May 2012 , Association of Food Scientists \& Technologists (India) 2012.

[4] Pederson, C.S. and Luh, B.S. (2006).Pickling and fermentation of vegetables.AVI Van Nostrand Reinhold, New York.

[5] Peeyush Kumar and Sapna Mishra, Insecticidal properties of Mentha species, Received 21 December 2010, Received in revised form 17 February 2011,
Accepted 24 February 2011, Available online 23 March 2011.

[6] Rebecca L. Surles, NingWeng,and Philipp W. Simon,Carotenoid Profiles and Consumer Sensory Evaluation of Specialty Carrots (Daucuscarota, L.) of Various Colors, J. Agric. Food Chem. 2004, 52, 341734213417.

[7] Rita M. Heuertz, and Edward Weiss, Whole Beetroot Consumption Acutely Improves Running Performance, Accepted 29 November 2011.

[8] S. Bhat, P. Kaushal, M. Kaurand H. K. Sharma,Coriander (CoriandrumsativumL.): Processing,nutritional and functional aspects , Accepted 26 November, 2013.

[9] S. T. Talcott, L. R. Howard, and C. H. Brenes, Antioxidant Changes and Sensory Properties of Carrot Puree Processed with and without Periderm Tissue, J. Agric. Food Chem. 2000, 48, 1315-1321.

[10] Sanjay K Banerjee and Subir K Maulik,Effect of garlic on cardiovascular disorders.Nutrition Journal 2002, 1:4.

[11] Seung Koo Lee (2003),Preparation of Kimchi and Other Preserved Vegetables,Department of Horticulture,Seoul National University,Suwon 441-744.

[12] Sun-Jung Park and Jin-Hee Chang, Microbiological Analysis of Dongchimi, Korean Watery RadishKimchi, at the Early and Mid-phase Fermentation, Food Sci. Biotechnol.Vol. 17, No. 4, pp. $000 \sim 000$ (2008).

[13] SylwesterSmolenandWłodzimierzSady, The effect of various nitrogen fertilization and foliar nutrition regimes on the concentrations of sugars, carotenoids and phenolic compounds in carrot .journal homepage 19 November 2008.

\section{Volume 6 Issue 12, December 2017}

